\title{
OCCURRENCE OF AGONE ALOSA AGONE IN LAKE SHKODRA, ALBANIA IN SYMPATRY WITH TWAITE SHAD ALOSA FALLAX NILOTICA.
}

\author{
N. RAKAJ (1), A.J. CRIVELLI (2)*
}

(1) University of Tirana, Department of Biology, TIRANA, Albania.

(2) Station Biologique de la Tour du Valat, Le Sambuc, 13200 ARLES, France. Tel. : 0033490972013 ; Fax : 003390972019

E-mail : a.crivelli@ tour-du-valat.com

* Corresponding author.

\section{ABSTRACT}

Twaite shad, Alosa fallax nilotica occurs in Lake Shkodra (Albania) in sympatry with Agone Alosa agone. Differences in morpho-meristic variables, in the biology and the ecology of the two species are presented and potential explanations for the occurrence of these shad populations in sympatry are discussed.

Key-words : Alosa fallax, Alosa agone, sympatry, Lake Shkodra, Albania.

\section{PRÉSENCE DE L'ALOSE DE LAC, ALOSA AGONE, DANS LE LAC SHKODRA EN ALBANIE EN SYMPATRIE AVEC L'ALOSE FEINTE ALOSA FALLAX NILOTICA.}

\section{RÉSUMÉ}

Dans le lac Shkodra (Albanie), on observe l'alose feinte Alosa fallax nilotica en sympatrie avec l'alose de lac Alosa agone. La forme des deux espèces diffère significativement comme le montre l'analyse discriminante de quatorze caractères morphoméristiques. Des différences entre les deux espèces sont observées dans leur biologie et leur écologie. Des hypothèses sont présentées pour expliquer la présence de ces deux espèces en sympatrie.

Mots-clés : Alosa fallax, Alosa agone, sympatrie, Lac Shkodra, Albanie.

\section{INTRODUCTION}

Shad species and subspecies are numerous in the Mediterranean region (HOESTLANDT, 1991 ; KOTTELAT, 1997). Most of them are anadromous and few as Agone Alosa agone (Scopoli, 1786), Alosa macedonica (Vinciguerra, 1921) and Alosa caspia vistonica (Economidis and Sinis, 1986), of which only landlocked populations 
are known (ECONOMIDIS and SINIS, 1986 ; QUIGNARD and DOUCHEMENT, 1991). The latter have only been described in Italy. Agone was first described in lakes belonging to the Po river catchment in the Lombardy region, northern Italy. Since then, Agone has been introduced into lakes of Central Italy, and occurs also in Sardinia as a result of reservoir building. Fish became trapped in impoundments behind dams and landlocked populations developed, for example since 1922 at Omodeo and since 1957 at Flumendosa (QUIGNARD and DOUCHEMENT, 1991). Agone is becoming increasingly rare in other northern Italian lakes (GIUSSANI, 1989 ; BERNADI et al., 1990 ; MÜLLER and MENG, 1992).

This paper establishes the occurrence of Alosa agone in Lake Shkodra (= Lake Skadar, $371 \mathrm{~km}^{2}$, two thirds in Former Yugoslavia and one third in Albania ; Figure 1) in sympatry with $A$. fallax nilotica, the anadromous Twaite shad (RAKAJ, 1995). It assesses the presence of the two species using morpho-meristic data, the differences in their biology, and discusses potential explanations for the occurrence of this landlocked Agone population and how it coexists with the Twaite shad population.

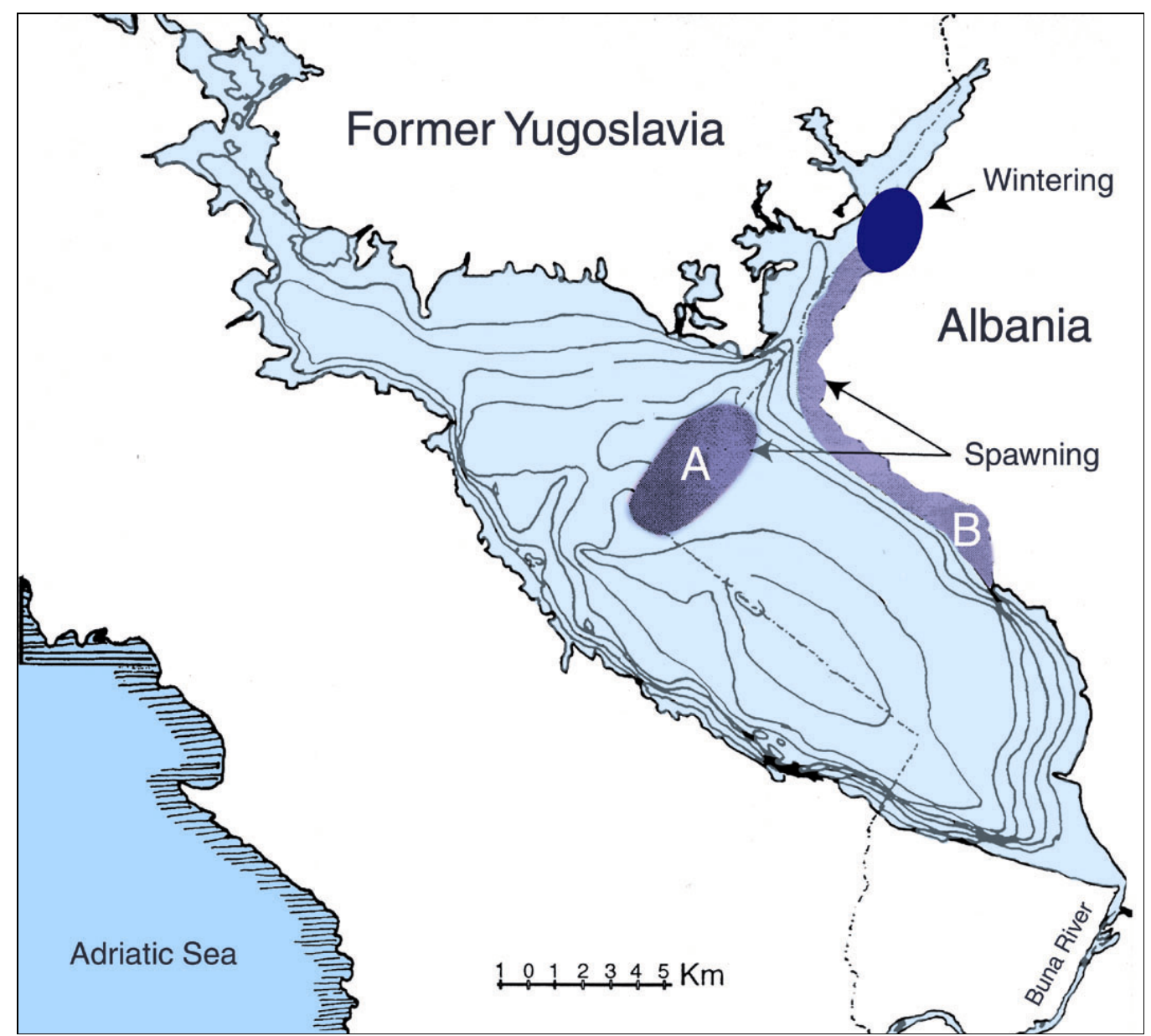

Figure 1

The study area with the spawning area (A) of $A$. f. nilotica and the spawning (B) and wintering areas of $A$. agone.

Figure 1

La zone d'étude avec la répartition des zones du frai (A) d'A. f. nilotica et du frai (B) et d'hivernage d'A. agone. 


\section{MATERIAL AND METHODS}

Fish were collected by professional fishermen in the1990s. Nine morphometric and five meristic measurements were taken with a caliper to the nearest $0.05 \mathrm{~mm}$ on 11 A. fallax nilotica and on $27 \mathrm{~A}$. agone. These morpho-meristic variables were compared using a discriminant analysis. Age was estimated using scales. Information on spawning areas and spawning period were obtained from fishermen, by dissecting shad caught and assessing their gonad status.

\section{RESULTS}

Both species do not overlap, indicating clearly that there are two distinct shad populations in Lake Shkodra, well differentiated by their morpho-meristic features (Figure 2 ; Table 1). All the morpho-meristic variables to the exception of three of them $(P>0.15$; Ante-ventral distance / Standard length, $r=-0.27$; Pelvian fin rays, $r=-0.26$; Ventral fin rays, $r=0.00)$ do contribute $(P<0.001)$ to the discriminant axis. This analysis indicates also that there is no hybridisation between the two shad species.

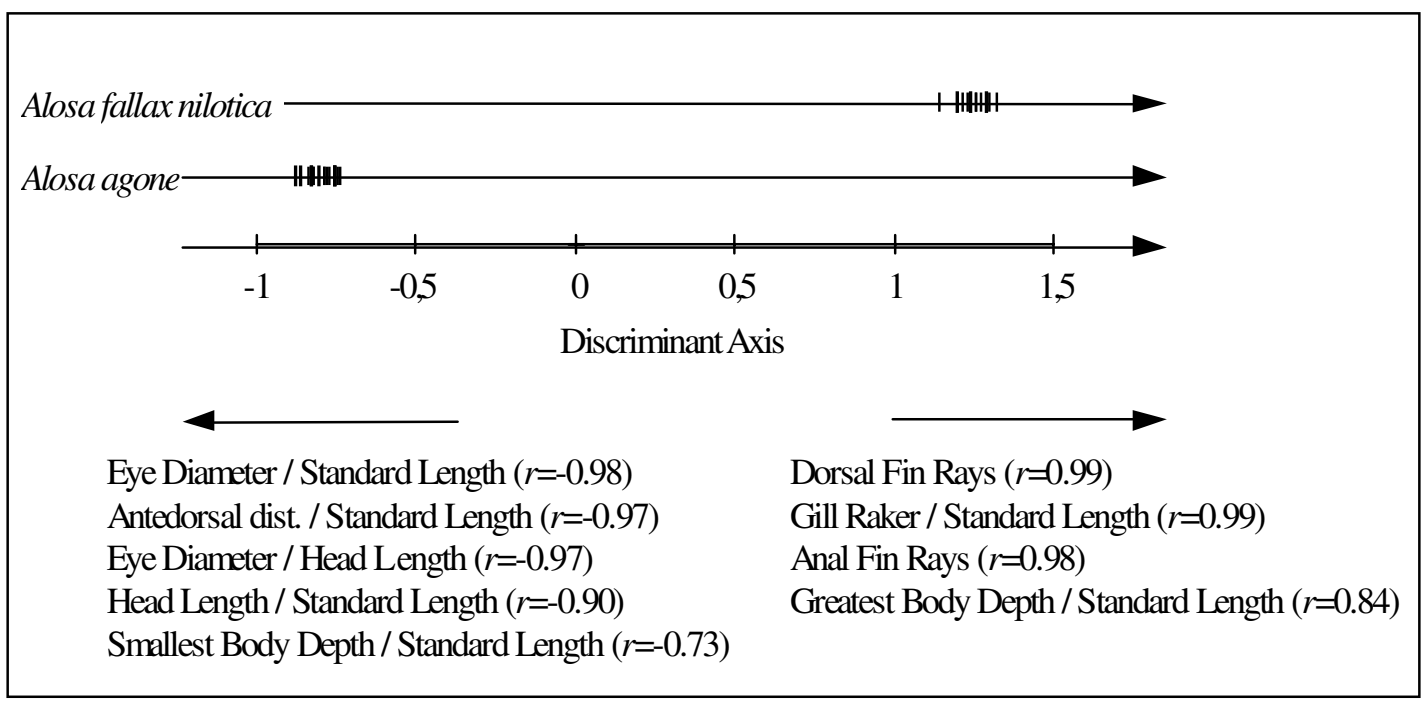

Figure 2

Separation of Alosa fallax nilotica and $A$. agone by morpho-meristic characteristics as shown by discriminant analysis. Only variables with significant correlations with the discriminant axis $(P<0.001)$ appear in the figure.

\section{Figure 2}

Séparation d'Alosa fallax nilotica et d'A. agone par l'analyse discriminante de quatorze caractères morpho-méristiques. Seules les variables qui contribuent significativement à l'axe discriminant $(P<0.001)$ sont listées.

Spawners of $A$. $f$. nilotica $(\mathrm{N}=91)$ are between 3 and 8 years old with a maximum total length of $60 \mathrm{~cm}$ and a weight of more than two kilograms. Spawners of $A$. agone $(\mathrm{N}=32)$ are between 2 and 5 years old with a maximum total length of $33 \mathrm{~cm}$ with a weight of 340 grams. The spawning period as well as the spawning areas (sand and gravels) of the two species do not overlap (Figure 1) : April-May in the middle of the lake with a water temperature between 14.1 and $20^{\circ} \mathrm{C}$ for $A$. $f$. nilotica and June-July on the shore of the 
lake with a water temperature between 23.6 and $28.2^{\circ} \mathrm{C}$ for $A$. agone. Fecundity is much higher for $A$. $f$. nilotica with $400000-500000$ eggs per kilogram of fish compared to 200 000-300 000 per kilogram of fish for $A$. agone.

Table I

Morphometric and meristic characteristics of Alosa agone and Alosa fallax nilotica from Lake Shkodra.

\section{Tableau I}

Caractéristiques morphométriques et méristiques de Alosa agone et Alosa fallax nilotica dans le lac de Shkodra.

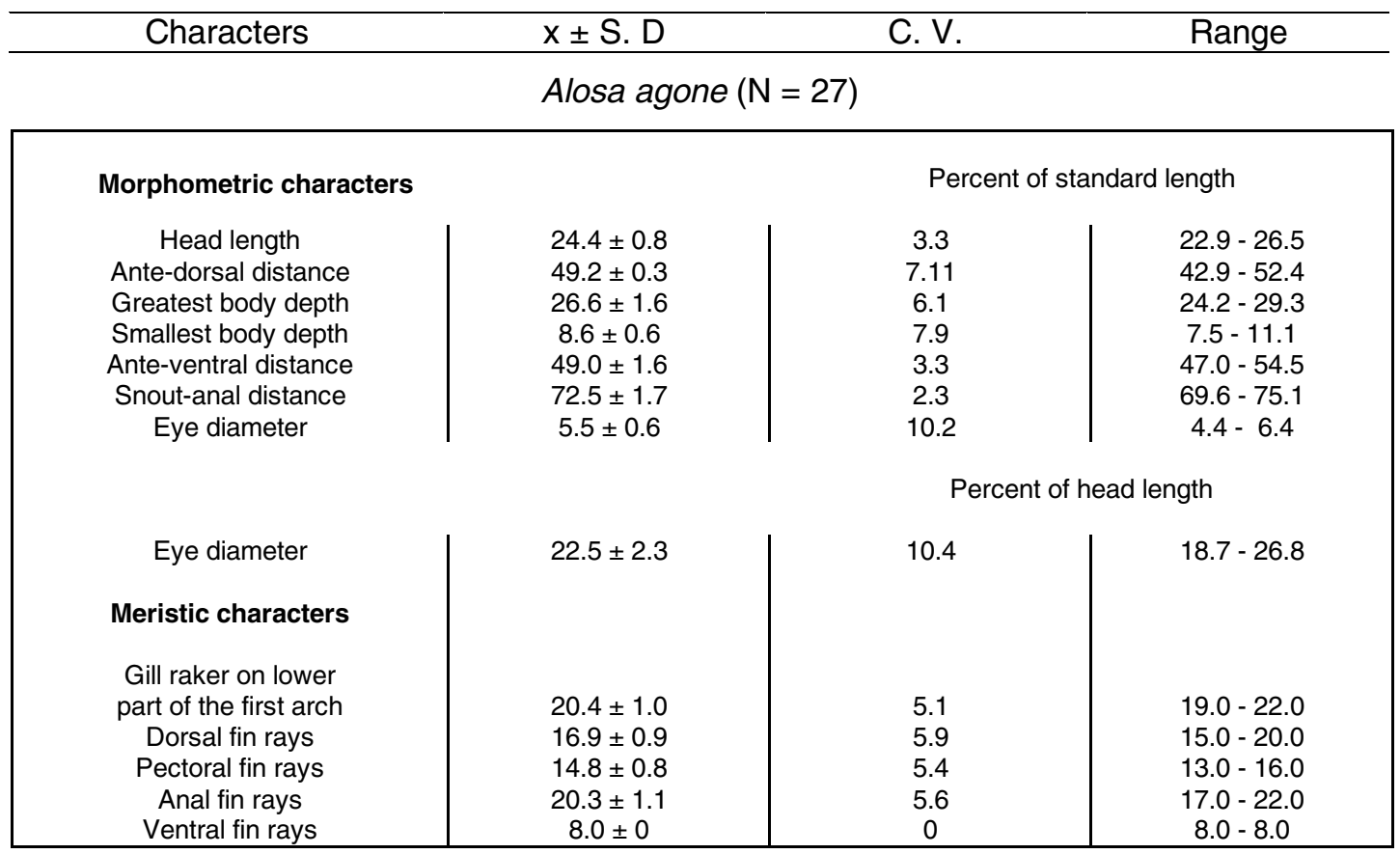

Alosa fallax nilotica $(\mathrm{N}=11)$

Morphometric characters

Head length

Ante-dorsal distance

Greatest body depth

Smallest body depth

Ante-ventral distance

Snout-anal distance

Eye diameter

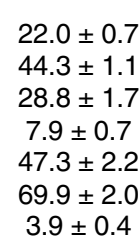

$22.0 \pm 0.7$

$44.3 \pm 1.1$

$28.8 \pm 1.7$

$47.3 \pm 2.2$

$3.9 \pm 0.4$

$17.5 \pm 1.6$

Eye diameter

Meristic characters

Gill raker on lower part of the first arch

Dorsal fin rays

Pectoral fin rays

Anal fin rays

Ventral fin rays
Percent of standard length

$$
\begin{gathered}
3.2 \\
2.6 \\
5.9 \\
8.5 \\
4.7 \\
2.9 \\
10.9
\end{gathered}
$$

$20.7-22.8$

$43.3-46.5$

$26.4-31.7$

$7.0-9.0$

$45.0-52.5$

$67.5-73.2$

$3.4-4.8$

Percent of head length

9.4

$15.0-20.9$

$21.0-26.0$

$15.0-17.0$

$13.0-16.0$

$18.0-20.0$

$8.0-8.0$ 
According to fishermen, Twaite shad leave the lake as soon as the water temperature drops in winter, but Agone stay in the lake and spend the winter in deep water at the north-eastern part of the lake (Figure 1) in cryptodepressions, many of which contain sublacustrine springs with constant water temperature which attract numerous fish species during the winter (LASCA et al.,1981). There is a commercial fishery on shad in the lake Shkodra (STEIN, MECOM and IVANOVIC, 1975) and on the river Buna during migration.

\section{DISCUSSION}

VUKOVIC (1961), in his study on Twaite shad of the Neretva River and Lake Skadar, mentioned that some individuals of shad were not anadromous and stayed in the lake, but he did not mention whether these individuals were different morphologically or in their biology. Later, IVANOVIC (1973) and KNEZEVIC (1981) mentioned only A. fallax nilotica in their list of fishes of Lake Shkodra. The biological data from our study are in accordance with similar published data on both species (BERG and GRIMALDI, 1966 ; SERVENTI, VITALI and GANDOLFI, 1990).

The Agone population of Lake Shkodra is probably today the only natural population of Agone in the Mediterranean region, all the other being stocked by man or resulted from a dam building. In Lake Shkodra, both resident and anadromous shad populations exist sympatrically, raising intriguing questions about how they rose and how coexistence persists. Two main hypotheses may be proposed : (a) they are alternative life-history phenotypes within a single population or (b) they are genetically distinct, reproductively isolated populations that have arisen either sympatrically or allopatrically and have since came into contact. Although the precise origin of Lake Shkodra is unknown, the lake probably formed during the Tertiary and/or Quaternary periods by dissolution of limestone in an active tectonic basin (BEETON, 1981). It is more likely that the two species have arisen allopatrically, the lake Shkodra being isolated 6 millions year ago from any seawater, when the Mediterranean sea dried out completely for the last time (HSÜ, RYAN and CITA, 1973 ; HSÜ et al., 1977 ; BIANCO, 1990). Twaite shad were then trapped and adapted themselves to an entire life in freshwater. This isolation lasted sufficiently to allow the freshwater population, Alosa agone to develop its own life history traits, quite different from the anadromous shad, and to diverge morphologically. When the connection with the sea was re-established, anadromous Twaite shad migrated again into Lake Shkodra and were therefore in sympatry with its freshwater congener. However, because the spawning time and the spawning grounds of the two species do not overlap, no hybridisation occurs between the two (Figure 2) and this reproductive isolation allows the freshwater species to persist. It would be interesting now to test genetically these two species to assess whether $A$. agone population diverge genetically to the extent that reproduction between them would be impossible. Recent work on the genetics of shad (BOISNEAU, MENESSONBOISNEAU and GUYOMARD, 1992 ; ALEXANDRINO et al., 1993 ; ALEXANDRINO, FERRAND and ROCHA, 1996) should help in this future analysis.

\section{ACKNOWLEDGEMENTS}

This work has been funded by the Foundation Sansouire. We thank Dr G. POIZAT for helping with the disciminant analysis. 


\section{REFERENCES}

ALEXANDRINO P.J., FERRAND N., ROCHA J., 1996. Genetic polymorphism of a haemoglobin chain and adenosine deaminase in European shads : evidence for the existence of two distinct genetic entities with natural hybridization. J. Fish Biol., 48, 447-456.

ALEXANDRINO P.J., SOUSA C., PEREIRA A., FERRAND N., 1993. Genetic polymorphism of adenosine deaminase (ADA ; E.C. 3.5.4.4.) in alis shad Alosa alosa and twaite shad, Alosa fallax. J. Fish Biol., 43, 951-953.

BEETON A.M., 1981. Physical conditions of Lake Skadar and its basin. In : KARAMAN G.S. and BEETON A.M. (Eds.), The biota and limnology of Lake Skadar, 15-17, Univerzitet Veljko Vlahovic, Titograd ; Smithsonian Institution, Washington ; Center for Great Lakes Studies, University of Wisconsin, Wisconsin.

BERG A., GRIMALDI E., 1966. Biologia dell' Agone (Alosa fallax lacustris) del lago Maggiore. Memorie dell' Istituto Italiano di Idrobiologia, 20, 41-83.

BERNADI R., GIUSSANI G., MANCA M., RUGGIU D. 1990. Trophic status and the pelagic system in Lago Maggiore. Hydrobiologia, 191, 1-8.

BIANCO P.G., 1990. Potential role of the palaeohistory of the Mediterranean and Paratethys basins on the early dispersal of Euro-Mediterranean freshwater fishes. Ichthyological Exploration of Freshwaters, 1, 167-184.

BOISNEAU P., MENESSON-BOISNEAU C., GUYOMARD R., 1992. Electrophoretic identity between allis shad Alosa alosa (L.) and twaite shad, $A$. fallax (Lacépède). Journal Fish Biology, 40, 731-738.

ECONOMIDIS P.S., SINIS I., 1986. Situation taxinomique et comparaisons des Aloses (Pisces, Clupeidae) provenant des lacs Volvi et Vistonis (Grèce). Description d'une nouvelle sous-espèce : Alosa caspia vistonica. Journal of Natural History, 20, 723734.

GIUSSANI G., 1989. Lago Maggiore fish community evolution. Memorie dell' Istituto Italiano di Idrobiologia, 46, 125-135.

HOESTLAND H., 1991. The Freshwater Fishes of Europe. Clupeidae, Anguillidae. AulaVerlag, Wiesbaden, $447 \mathrm{p}$.

HSÜ K.J., RYAN W.B.F., CITA M.B., 1973. Late Miocene desiccation of the Mediterranean. Nature, 242, 240-244.

HSÜ K.J., MONTADERT L., BERNOULLI D., CITA M.B., ERICKSON A., GARRISON R.E., KIDD R.B., MĖLIERÉS F., MÜLLER C., WRIGHT R., 1977. History of the Mediterranean salinity crisis. Nature, 267, 399-403.

IVANOVIC B.M., 1973. Ichthyofauna of Skadar Lake. Institution for Biological and Medical Research in Montenegro, Titograd, Serbia. $146 \mathrm{p}$.

KNEZEVIC B., 1981. Fishes of Lake Skadar. In : KARAMAN G.S. and BEETON A.M. (Eds.), The biota and limnology of Lake Skadar, 312-316, Univerzitet Veljko Vlahovic, Titograd ; Smithsonian Institution, Washington ; Center for Great Lakes Studies, University of Wisconsin, Wisconsin.

KOTTELAT M., 1997. European freshwater fishes. Biologia, Bratislava 52 / Supplement, 5, $1-271$.

LASCA N.P., RADULOVIC V., RISTIC R.J., CHERKAUER D.S., 1981. Geology, hydrology, climate and bathymetry of Lake Skadar. In : KARAMAN G.S. and BEETON A.M. (Eds.), The biota and limnology of Lake Skadar, 17-38, Univerzitet Veljko Vlahovic, Titograd ; Smithsonian Institution, Washington ; Center for Great Lakes Studies, University of Wisconsin, Wisconsin.

MÜLLER R., MENG H.J., 1992. Past and present state of the ichthyofauna of Lake Lugano. Aquatic Sciences, 54, 338-350.

QUIGNARD J.P., DOUCHEMENT C., 1991. Alosa fallax lacustris (Fatio, 1890). In: HOESTLAND H. (ed.), The Freshwater Fishes of Europe. Clupeidae, Anguillidae, 257-264, Aula-Verlag, Wiesbaden.

RAKAJ N., 1995. Iktiofauna e Shqiperise. Shtepia Botuese «Libri Universitar », Tirana, Albania, $700 \mathrm{p}$. 
SERVENTI M., VITALI R., GANDOLFI G., 1990. Biologia e biometria dei riproduttori di alosa, Alosa fallax (Lacépède), in migrazione nel delta del Po. Rivista di Idrobiologia, 29, 469-475.

STEIN R.A., MECOM J.O., IVANOVIC B., 1975. Commercial exploitation of fish stocks in Skadar Lake, Yugoslavia, 1947-1973. Biol. Conserv., 8, 1-18.

VUKOVIC T., 1961. Populacije i mrescenje Alosa fallax nilotica (Geoffroy) u vodama Neretva is Skadarskojezera. Godisnjak Bioloskog Instituta Univerziteta u Sarajevu, 14, 85-178. 
